\title{
IMPLIKASI FALSAFAH SIRI' NA PACCE PADA MASYARAKAT SUKU MAKASSAR DI KABUPATEN GOWA
}

\author{
Rizal Darwis dan Asna Usman Dilo \\ Fakultas Syariah dan Ekonomi Islam IAIN Sultan Amai Gorontalo \\ Jl. Gelatik No. 1 Gorontalo, email: rizaldarwis2011@yahoo.co.id
}

\begin{abstract}
Articulating the religion in the life of human is a phenomenon in the actual practice. Religion consists of beliefs, dogmas, traditions, practices and rituals. A faith people who was born into a religious tradition wounld inherit and take all these aspects directly and believed that everything inherited was essential and integral aspect of religion. From this context, religious understanding begined from understanding the legacy that has been determined and doctrined unilaterally without passing personal lane that bassically resulted a conviction and a strong understanding. At the life level, people had a philosophy of their life. This was reflected in a philosophy siri' na pacce that was hold by tribe Makassar as guidelines in their daily activities.
\end{abstract}

Mengartikulasikan agama dalam ranah kehidupan manusia merupakan sesuatu yang fenomenal dalam praktik yang sebenarnya. Agama terdiri dari keyakinan, dogma, tradisi, praktik dan ritual. Seorang yang beriman yang dilahirkan dalam tradisi yang religius akan mewarisi dan mengambil semua aspek ini begitu saja dan meyakini bahwa segala sesuatu yang diwarisi merupakan aspek esensial dan integral dari agama. Dari konteks ini, pemahaman keagamaan merupakan pemahaman yang sama karena berawal dari pemahaman warisan yang sudah ditentukan dan didoktrinkan secara sepihak tanpa melewati jalur penelusuran pribadi yang pada dasarnya akan menghasilkan sebuah keyakinan dan pemahaman yang kukuh. Pada tataran kehidupan, masyarakat tentunya memiliki falsafah dalam menjalani kehidupan mereka. Hal ini tergambar pada falsafah yang dipegangi oleh 
masyarakat Suku Makassar, yaitu falsafah siri' na pacce yang menjadi pedoman dalam pergaulan mereka sehari-hari.

Key words: philosophy, siri' na pacce, Makassar tribe, Islamic law

\section{Pendahuluan}

Manusia merupakan makhluk sosial yang dalam memenuhi kebutuhan hidupnya harus berinteraksi dengan orang lain, dan oleh karenanya manusia cenderung hidup berkelompok dan bermasyarakat. Kelompok-kelompok ini kemudian bersepakat membuat aturan-aturan yang mengatur sikap dan bertingkah laku dalam lingkungannya. Aturan ini kemudian berkembang menjadi prinsip, pedoman dan pandangan hidup sebuah masyarakat yang harus dipatuhi dan dijalankan oleh setiap individu dalam masyarakat tersebut.

Pandangan hidup suatu komunitas masyarakat sangat mempengaruhi tingkah laku individu yang hidup dalam lingkungan masyarakat tersebut, sehingga apabila seseorang ingin bergaul dan bertahan hidup dalam kelompok masyarakat tertentu, maka ia harus dapat mengetahui dan mengenal kebiasaan (adat), pandangan (prinsip) hidup dan aturan-aturan (norma) yang berlaku dalam masyarakat itu.

Pada masyarakat suku Makassar, khususnya yang berdomisili di daerah Kabupaten Gowa, mereka masih berpegang pada prinsip (falsafah) hidup siri' na pacce, di samping beberapa prinsip-prinsip hidup yang lain. Falsafah siri' na pacce yang sudah ada dan diperpegangi sejak dahulu oleh masyarakat Suku Makassar serta merupakan pandangan hidup yang perlu dipertahankan dan perlu diselaraskan dengan ajaran dan akidah Islam, sebab pemahaman dan keyakinan masyarakat tentang makna dan tujuan siri' na pacce pada saat ini mulai terkikis akibat perkembangan zaman dan pengaruh pemikiran serta budaya dari luar.

Ada ungkapan suku Makassar yang berbunyi "punna tena siriknu, paccenu seng pakania" (kalau tidak ada siri'-mu pacce-lah yang kau pegang teguh) (Limpo, 1995: 87). Ungkapan ini menggambarkan bahwa antara siri' dan pacce selalu seiring sebagai satu kesatuan yang tidak terpisahkan. Apabila siri' dan pacce sebagai pandangan hidup tidak dimiliki oleh seseorang, maka akan dapat berakibat orang tersebut bertingkah laku melebihi binatang (tidak punya malu/siri') karena tidak memiliki unsur kepedulian sosial dan hanya mau menang sendiri (tidak merasakan sedih/pacce).

Falsafah siri' dipergunakan oleh orang Makassar untuk membela 
kehormatan terhadap orang-orang yang mau menghina atau merendahkan harga dirinya, keluarganya maupun kerabatnya, sedangkan falsafah pacce dipakai untuk membantu sesama anggota masyarakat yang berada dalam kesusahan atau mengalami penderitaan.

Pandangan masyarakat Makassar tentang konsep dan tujuan siri' dan pacce yang sebenarnya mulai terkikis, bahkan dalam beberapa contoh kasus telah terjadi penyalahan maksud dan tujuan siri'. Misalnya ketika seorang pemuda yang tanpa sebab jelas (dalam keadaan mabuk) mengganggu orang yang lewat di depannya dan terjadi perkelahian yang menyebabkan si pemuda mengalami luka berat, maka teman-teman pemuda tersebut mengadakan pembalasan dengan alasan siri' (mempertahankan harga diri). Hal ini malah memperbesar masalah yang dapat berakibat pertikaian antar kelompok, sehingga timbul kesan orang Makassar itu "Pabbambangangi na tolo" (pemarah lagi bodoh) dan "Eja tonpi seng na doang" (nanti setelah merah baru terbukti udang).

Ungkapan tersebut muncul sebab apabila orang Makassar merasa bahwa harga dirinya direndahkan di depan umum, maka ia akan langsung memberikan pembalasan. Dengan kata lain, kalau siri' sudah dilanggar, maka harus langsung dibayar, nanti setelah itu dipikirkan akibatnya. Hal ini tidaklah sepenuhnya benar, karena tindakan balasan yang dilakukan bukan karena mereka bodoh, akan tetapi semata-mata hanya ingin membela harga dirinya dan mendorong untuk dapat menjaga kehormatan diri, yang terpenting ialah harga diri yang dibela memang benar dan patut untuk dibela dan dipertahankan.

Ada beberapa penyebab timbulnya siri', misalnya: apabila ada seorang pria dan wanita yang menikah tanpa persetujuan keluarga mempelai wanita (kawin lari), maka hal tersebut dianggap siri' (memalukan/merusak harga diri keluarga); apabila ada orang yang ditampar di depan umum, maka hal tersebut termasuk siri' (dipermalukan); apabila ada seorang yang pergi merantau untuk memperbaiki kehidupannya, maka dia merasakan malu (siri') apabila harus pulang tanpa hasil (gagal); apabila ada orang yang melanggar aturan agama (berzina), maka orang tersebut telah melanggar siri' (berbuat hal yang memalukan), dan masih banyak contoh lainnya.

Dalam ajaran Islam, siri' sangat dijunjung tinggi karena apabila kita mempertahankan harga diri dengan alasan yang jelas dan merasakan malu bila akan melakukan perbuatan yang salah maka hal tersebut sangat dibenarkan. Apabila seseorang sudah tidak memiliki lagi perasaan malu untuk berbuat apa saja maka segala perbuatan yang melanggar aturan-aturan agama, adat, hukum dan norma-norma yang lain akan dilakukannya tanpa beban apapun 
(Ya'qub, 1996: 111).

Dari penjelasan di atas, maka falsafah siri' yang dijadikan prinsip oleh masyarakat suku Makassar dapat sejalan dengan ajaran Islam, namun tergantung bagaimana upaya pemahaman masyarakat dalam penegakan siri' sesuai dengan tuntunan dan ajaran Islam. Selain itu falsafah pacce yang berarti turut merasakan dan membantu orang yang mengalami penderitaan, karena manusia semuanya ini bersaudara sesuai dengan firman Allah SWT dalam al Quran "sesungguhnya orang-orang mukmin itu bersaudara, karena itu damaikanlah antara kedua saudaramu (yang berselisih) dan bertakwalah kepada Allah agar kamu mendapat rahmat" (QS al Hujurat: 10).

Oleh sebab itu, maka perlu dijelaskan tentang maksud dan tujuan siri' na pacce agar dapat memperbaiki pemahaman yang agak menyimpang dari makna dan tujuan sebenarnya. Di samping itu perlu adanya penyelarasan terhadap ajaran Islam, sebab mayoritas masyarakat Makassar khususnya di kabupaten Gowa beragama Islam agar senantiasa dalam kehidupan dan bertingkah laku sehari-hari menggambarkan budaya Makassar dan sekaligus bernuansa Islami.

\section{Pengertian Siri' dan Pacce}

Kata siri' dalam bahasa Makassar berarti malu atau rasa malu, maksudnya siri' (tuna) lanri anggaukanna anu kodi, artinya malu apabila melakukan perbuatan yang tercela. Sekalipun kata siri' tidak hanya dipahami menurut makna harfiah tersebut.

Pengertian siri' menurut istilah dapat dilihat dari pendapat beberapa tokoh, seperti: B. F. Matthes menjelaskan sebagaimana dikutip oleh Koentjaraningrat, bahwa istilah siri' diterjemahkan dengan malu, rasa kehormatannya tersinggung dan sebagainya (Koentjaraningrat, 1995: 279). Menurut C.H. Salam Basjah yang dikutip oleh Mattulada memberi tiga pengertian kepada konsep siri', yaitu: Pertama ialah malu, kedua, merupakan daya pendorong untuk membinasakan siapa saja yang telah menyinggung rasa kehormatan seseorang, dan ketiga ialah sebagai daya pendorong untuk bekerja atau berusaha sebanyak mungkin (Mattulada, 1995: 62). Pengertian siri' juga diungkapkan oleh M. Natzir Said, bahwa siri' adalah perasaan malu yang memberi kewajiban moril untuk membunuh pihak yang melanggar adat, terutama dalam soal-soal hubungan perkawinan (Koentjaraningrat, 1995: 280).

Siri' pernah pula dibicarakan dan dikaji pada Seminar Nasional yang diselenggarakan oleh Komando Daerah Kepolisian (KOMDAK) XVIII 
Sulselra bekerjasama dengan Universitas Hasanuddin, bertempat di ruang pola Gubernur Sulawesi Selatan pada tanggal 11 Juli 1977 sampai dengan tanggal 13 Juli 1977 dengan tema "Mengolah Masalah Siri' di Sulawesi Selatan Guna Peningkatan Ketahanan Nasional dalam Menunjang Pembangunan Nasional.” Adapun hasil seminar tersebut memberikan konsep dan batasan tentang siri' antara lain:

1. Siri' dalam sistem budaya adalah pranata pertahanan harga diri, kesusilaan dan hukum serta agama sebagai salah satu nilai utamanya yang mempengaruhi dan mewarnai alam pikiran, perasaan dan kemauan manusia. Sebagai konsep budaya, ia berkedudukan regulator dalam mendinamisasi fungsi-fungsi struktrur dalam kebudayaan.

2. Siri' dalam sistem sosial, adalah mendinamisasi keseimbangan eksistensi hubungan individu dan masyarakat untuk menjaga kesinambungan kekerabatan sebagai dinamika sosial terbuka untuk beraluh peranan (bertransmisi), beralih bentuk (bertranformasi), dan ditafsir ulang (re-interpretasi) sesuai dengan perkembangan kebudayaan nasional, sehingga siri' dapat ikut memperkokoh tegaknya filsafat bangsa Indonesia, Pancasila.

3. Siri' dalam sistem kepribadian, adalah sebagai perwujudan konkrit didalam akal budi manusia yang menjunjung tinggi kejujuran, keseimbangan, keserasian, keimanan dan kesungguhan untuk menjaga harkat dan martabat manusia (Moein, 1990: 42).

Konsep siri' berdasarkan pengertian bahasa, istilah dan hasil seminar tersebut dapat memberikan sumbangan pemikiran kepada masyarakat secara umum tentang makna dan tujuan siri' yang patut untuk diyakini, dilaksanakan dan dipertahankan dalam kehidupan sehari-hari. Dari seluruh pengertian siri' tersebut, maka dapat disimpulkan bahwa siri' adalah suatu sistem nilai sosial, budaya dan kepribadian yang merupakan pranata pertahanan harga diri dan martabat manusia sebagai individu dan anggota masyarakat.

Adapun pengertian pacce secara harfiah, yaitu pacce berarti perasaan pedis, perih atau pedih (Limpo, 1995: 91). Sedangkan pengertian pacce menurut istilah, antara lain: pacce adalah suatu perasaan yang menyayat hati, pilu bagaikan tersayat sembilu apabila sesama warga masyarakat atau keluarga atau sahabat ditimpa kemalangan (musibah) (Moein, 1990: 33). Pacce ini berfungsi sebagai alat penggalang persatuan, solidaritas, kebersamaan rasa kemanusiaan dan memberi motivasi pula untuk berusaha sekalipun dalam 
keadaan yang sangat pelik dan berbahaya (Limpo, 1995: 91).

Dari pengertian di atas jelaslah bahwa pacce dapat memupuk rasa persatuan dan kesatuan bangsa, membina solidaritas antara manusia agar mau membantu seseorang yang mengalami kesulitan. Sebagai contoh seseorang mengalami musibah, jelas masyarakat lainnya turut merasakan penderitaan yang dialami rekannya itu dan segera pada saat itu pula mengambil tindakan untuk membantunya baik berupa materi maupun non materi. Perasaan ini merupakan suatu pendorong ke arah solidaritas dalam berbagai bentuk terhadap mereka yang ditimpa kemalangan itu.

\section{Sejarah Awal Siri' dan Pacce}

Siri' na pacce merupakan budaya yang telah melembaga dan dipercaya oleh suku Makassar, maka untuk membahas lebih lanjut tentang falsafat tersebut perlu ada penelitian dan pengkajian tentang sejarah dan konsep siri' na pacce yang ada pada suku Makassar sejak zaman dahulu.

Suku Makassar yang mendiami sebagian wilayah Sulawesi Selatan merupakan penduduk asli yang sudah memiliki pranata budaya tersendiri, jauh sebelum resmi lahirnya kerajaan Gowa yang merupakan kerajaan dari Kawasan Timur Indonesia yang mempunyai pengaruh yang cukup besar. Kerajaan Gowa dimulai ketika kehadiran Tumanurunga di Takakbassia Tamalate, berdasarkan atas perjanjian pemerintahan antara Tumanurunga dengan Sembilan Kasuwiang yang kira-kira terjadi pada tahun 1300 M (Limpo, 1995: 23).

Untuk menggali sejarah tentang siri' na pacce, maka tulisan-tulisan tentang falsafah atau petuah-petuah tersebut dapat kita lihat pada tulisan lontarak. Adapun sejarah lahirnya huruf lontarak ialah dibuat oleh Daeng Pamatte ketika ia diperintahkan oleh Karaeng Tumapakrisik Kallonna didasari oleh kebutuhan kerajaan untuk dapat berkomunikasi secara tulis menulis dan agar peristiwa-peristiwa kerajaan dapat dicatat dalam tulisan.

Walaupun sejarah suku Makassar mulai tercatat pada masa Karaeng Tumapakrisik Kallonna, namun budaya siri' sudah menjadi adat istiadat dan falsafah hidup mereka sejak dahulu. Adapun pandangan suku Makassar tentang siri' dapat kita lihat dari beberapa istilah yang berkaitan dengan siri'.

Berikut ini beberapa istilah tentang siri' dan maknanya, antara lain: sirik (siri') sebagai harga diri atau kehormatan; mappakasiri', artinya dinodai kehormatannya; ritaroang sirik (siri'), artinya ditegakkan kehormatannya; passampo sirik (siri'), artinya penutup malu; tomasiri'na, artinya keluarga pihak yang dinodai kehormatannya; sirik (siri') sebagai perwujudan sikap tegas 
dami kehormatan tersebut; sirik (siri') sebagai pernyataan sikap tidak serakah (mangowa); sirik (siri') naranreng, artinya dipertaruhkan demi kehormatan; siriksirik (siri'-siri'), artinya malu-malu; palaloi siriknu (siri'nu), artinya tantang yang melawan; passirikia, artinya bela kehormatan saya; napakasirikka (napakasiri'ka), artinya saya dipermalukan; tau tena sirikna (siri'na), artinya orang tak ada malu, tak ada harga diri (Moein, 1990: 10).

Selain itu dalam tulisan lontarak terdapat petuah-petuah atau ungkapanungkapan yang berkenaan dengan konsep siri', antara lain:

1. Siritaji nakitau, artinya hanya siri', maka kita dinamakan manusia. Maksudnya seseorang yang tidak mempunyai siri', maka ia tidak ada artinya sebagai manusia (layak disebut binatang), karena sikap orang yang tidak mempunyai siri' seperti perbuatan binatang (tidak punya malu).

2. Sirikaji tojeng, siritaji tojeng, artinya hanya siri'lah yang benar. Maksudnya perasaan siri' atau malu karena melakukan perbuatan yang tercela, hal tersebut dianggap benar oleh hukum manapun (agama, adat dan negara).

3. Karaeng, siri' kuji ki atai, artinya Tuanku, hanya karena siri' maka tuan memperhamba saya. Maksudnya kedudukan (status sosial) seseorang sangat mempengaruhi sikap orang lain dalam kehidupan sosialnya.

4. Punna taenamo siri'ku, manna kupannobokangki, taenamo nalantanglantang, artinya manakala tidak ada lagi siri' ku, maka sekalipun aku menikamkan kerisku kepada tuan, tidaklah menjadi dalam lagi. Maksudnya apabila seseorang sudah tidak memiliki perasaan malu, maka orang tersebut sudah tidak mempunyai kehormatan dan kekuatan di hadapan orang lain.

5. Kaanne buttaya Gowa majarremi nikasirikang, artinya bahwasanya negeri Gowa ini telah ditekadkan guna membela siri'. Maksudnya bahwa kerajaan Gowa atau wilayah Gowa merupakan daerah yang sangat menjunjung dan menghargai falsafah siri' (Marzuki, 1995: 38).

Dalam pemahaman masyarakat Suku Makassar, kejayaan dan kebesaran suatu negeri bergantung kepada empat hal pokok, yaitu adat kebiasaan (Ada'), persamaan hukum (Rapang), undang-undang (Bicara), aturan mengenai strata sosial (Wari), dan aturan syariat Islam (Sara). Ada' sebagai pranata sosial yang mengatur segala aspek kehidupan dan kehidupan dan tata kelakuan sangat dihormati, dijunjung tinggi dan dipertahankan dengan teguh. Begitu 
pentingnya ada', maka bagi masyarakat suku Makassar, segala pengabaian terhadapnya dianggap sebagai pengkhianatan terbesar dan oleh karena itu perlu mendapat ganjaran yang setimpal, tidak jarang wujud ganjaran itu berupa pembunuhan.

\section{Pembagian Siri' dan Pacce}

Pada dasarnya siri' dan pacce merupakan suatu falsafah yang tidak dapat dipisahkan, karena antara satu dengan yang lainnya mempunyai keterkaitan makna dan hubungan, sehingga dalam hal pembagian siri' dan pacce, keduanya saling berkaitan erat.

Pembagian siri' dapat dikategorikan dalam dua hal, yaitu siri' berdasarkan penyebab timbulnya perasaan (dorongan), dan berdasarkan jenis atau bentuknya. Siri' dibagi berdasarkan penyebab timbulnya perasaan tesebut, yaitu:

1. Sirik (siri') yang berasal dari pribadi manusia yang merasakannya/ bukan kehendaknya (penyebabnya dari luar). Jadi, siri' ri-pakasirik, maksudnya dipermalukan oleh orang lain.

2. Sirik (siri') yang berasal dari pribadi orang itu sendiri (penyebab di dalam) disebut sirik ma sirik (siri' ma siri'), maksudnya malu yang berasal dari dirinya/keluarganya (Moein, 1990: 33).

3. Siri' dapat dikategorikan dalam empat (jenis) golongan, yaitu siri' yang dalam hal pelanggaran kesusilaan; siri' yang berakibat kriminal, siri' yang dapat meningkatkan motivasi untuk bekerja, dan siri' yang berarti malu-malu (Limpo, 1995: 87).

Jenis siri' yang pertama ialah siri' dalam hal pelanggaran kesusilaan. Berbagai macam pelanggaran kesusilaan yang dapat dikategorikan sebagai siri', seperti kawin lari (silariang, nilariang, dan erang kale), perzinahan, perkosaan, perbuatan salimarak, yaitu perbuatan hubungan seks yang dilarang karena adanya hubungan keluarga yang terlalu dekat, misalnya perkawinan antara ayah dengan putrinya, ibu dengan putranya dan sebagainya.

Jenis siri' kedua adalah siri' yang dapat berakibat kriminal. Siri' seperti ini, misalnya menempeleng seseorang di depan orang banyak, menghina dengan kata-kata yang tidak enak didengar dan sebagainya. Tamparan itu dibalas dengan tamparan pula, sehingga dapat terjadi perkelahian bahkan pembunuhan.

Jenis siri' ketiga ialah siri' yang dapat memberikan motivasi untuk meraih sukses, misalnya bila orang lain mampu berhasil mengapa kita tidak, sehingga suku Makassar kadang merantau ke daerah mana saja dan sesampainya di 
daerah tersebut mereka bekerja keras untuk meraih kesuksesan, sebab mereka akan malu bila pulang ke kampung halaman tanpa hasil.

Ada beberapa syair orang Makassar yang sesuai dengan jenis siri' tersebut, antara lain:

Takunjunga bangunturu', nakugunciri' gulingku, kualleanna tallanga na toali'a, artinya tidak begitu saja ikut angin buritan dan kemudian saya putar kemudiku, lebih baik tenggelam daripada balik haluan.

Bajikangngangi mateya ripa'rasanganna tauwa nakanre gallang-gallang na ammotereka tangngerang wassele, artinya lebih baik mati di negeri orang dimakan cacing tanah daripada pulang kampung tanpa membawa hasil (Limpo, 1995: xviii-xix).

Maksud kedua syair tersebut ialah apabila masyarakat suku Makassar sudah bertekad untuk meraih kesuksesan di negeri orang atau bertekad memperoleh kehidupan yang lebih layak, maka apapun rintangan yang menghadang akan tetap dihadapinya sampai keinginan mereka berhasil diperoleh.

Jenis siri' yang keempat ialah siri' yang berarti malu-malu. Siri' seperti ini sebenarnya dapat berakibat negatif bagi seseorang tapi ada pula positifnya, misalnya apabila ada seseorang yang diminta untuk tampil ke depan untuk menjadi protokol, ia merasa siri'-siri' (malu-malu). Hal ini dapat berakibat menghalangi bakat seseorang untuk dapat tampil di depan umum. Sisi positif dari siri'-siri' ini ialah apabila seseorang disuruh mencuri, maka ia merasa siri'siri' untuk melakukannya, apalagi bila ketahuan oleh orang.

Selain pembagian siri' di atas, maka pacce dapat dibagi berdasarkan penyebab timbulnya perasaan (dorongan) dan berdasarkan jenis atau bentuknya. Pacce dibagi berdasarkan penyebab timbulnya perasaan atau dorongan tersebut, yaitu:

1. Perasaan pacce karena melihat keluarga atau orang lain terkena musibah. Perasaan pacce seperti ini terkadang mendorong kita untuk memberikan bantuan kepada orang tersebut.

2. Perasaan pacce karena melihat keluarga atau teman teraniaya. Perasaan pacce ini mendorong kita untuk melakukan tindakan pembalasan terhadap orang yang melakukan penganiayaan tersebut, bahkan yang lebih parah, terkadang pembalasan tersebut langsung dilaksanakan tanpa berpikir atau mengetahui penyebab terjadinya pemukulan/ penganiayaan tersebut.

Pacce berdasarkan jenis atau bentuknya, antara lain:

1. Pacce yang berakibat kriminal. Pacce semacam ini misalnya ketika 
melihat keluarga atau temannya dipukul, maka timbul perasaan pedih dan keinginan untuk membalas perlakuan tersebut, sehingga terjadi perkelahian (kriminal).

2. Pacce yang memberikan dorongan untuk menolong. Pacce semacam ini misalnya ketika melihat keluarga, tetangga mengalami musibah, maka timbul perasaan atau keinginan untuk membantu.

3. Pacce yang dapat meningkatkan motivasi untuk bekerja. Pacce semacam ini misalnya ketika keluarga dalam keadaan susah, maka timbul perasaan ingin bekerja untuk menghidupi keluarga tersebut.

Dari pembagian siri' dan pacce tersebut di atas, maka dapat dipahami bahwa antara siri' dan pacce memiliki persamaan sifat yang memberikan dorongan hidup bagi masyarakat suku Makassar.

\section{Pengaruh Siri' dan Pacce dalam Kehidupan Masyarakat Suku Makassar di Kabupaten Gowa}

Masyarakat Gowa dalam memahami pengertian dan makna siri' telah berbeda dengan pemahaman masyarakat suku Makassar pada zaman dahulu (sejarah Makassar mulai tercatat pada Abad XVI, yaitu dengan ditemukannya huruf/tulisan lontarak). Hal ini disebabkan karena perkembangan zaman yang semakin pesat dengan membawa berbagai perubahan di segala bidang akibat kemajuan transportasi, komunikasi dan teknologi sehingga pembauran budaya antar masyarakat tidak dapat dibendung yang menyebabkan terjadinya pergeseran nilai-nilai budaya daerah.

Selain itu sikap dan tindakan yang seharusnya ditimbulkan akibat pelaksanaan maupun pelanggaran adat sudah mulai kurang diperhatikan dan dilaksanakan karena terbentur oleh berbagai hukum yang diatur dan dilaksanakan oleh negara dan bangsa Indonesia pada umumnya dan atau umat beragama pada khususnya. Perubahan-perubahan yang terjadi dalam lingkungan masyarakat mendorong untuk mengadakan pengkajian dan penelitian terhadap fenomena-fenomena yang terjadi agar memperoleh pengetahuan dan pemahaman tentang kehidupan masyarakat, khususnya di Kabupaten Gowa.

Pada tatanan masyarakat suku Makassar di Kabupaten Gowa masih menganggap bahwa falsafah siri' dan pacce masih harus dipercaya dan dipertahankan oleh masyarakat sesuai dengan pemahaman dan kondisi masyarakat yang ada di daerah tersebut serta hukum negara dan agama. Namun perlu diperhatikan pula falsafah siri' dan pacce yang diyakini dan dilaksanakan oleh masyarakat 
Gowa pada saat sekarang berangsur-angsur mulai berbeda dengan dengan konsep siri' na pacce yang ada pada zaman kejayaan kerajaan Gowa

Pada sebagian masyarakat Gowa menganggap budaya siri' dan pacce tidak bergeser akibat budaya dari luar, sebab mereka menganggap budaya tersebut masih ada dan nampak sampai sekarang. Sementara masyarakat yang menganggap budaya siri' dan pacce kadang-kadang bergeser akibat budaya dari luar, sebab mereka menilai budaya tersebut kurang diperhatikan oleh masyarakat pada saat ini, kalaupun ada perhatian hal tersebut pada persoalan yang sangat prinsipil atau pun dianggap sakral.

Sedangkan masyarakat yang mengangap falsafah siri' dan pacce sudah bergeser akibat budaya dari luar, sebab mereka melihat perkembangan generasi muda yang terpengaruh oleh budaya barat dan sikap serta perilaku masyarakat yang kurang mencerminkan adat suku Makassar. Hal ini nampak pada generasi muda sekarang, sebagian besar dari mereka sudah tidak mengetahui makna yang terkandung dari falsafah tersebut. Selain itu faktor ekonomi juga sangat mempengaruhi pergeseran budaya, sebab saat ini sebagian masyarakat Gowa memandang status sosial dipandang dari tingkat ekonominya.

Falsafah siri' bagi masyarakat Gowa dipandang sebagai budaya yang masih perlu dipertahankan, sehingga dalam memandang beberapa kasus yang berkaitan dengan persoalan siri', mereka masih menanggapi persoalan tersebut perlu diselesaikan dengan kekerasan. Masyarakat Gowa beranggapan bahwa terkadang ada persoalan siri' yang menimbulkan dorongan untuk melakukan pembalasan secara spontan karena dianggap sudah keterlaluan dan sangat merendahkan harga diri seseorang atau karena keterdesakan dengan alasan daripada saya yang terluka, lebih baik kamu yang saya dahului. Mereka memandang siri' sebagai sesuatu yang sangat sakral dan persoalan yang dapat dikegorikan sebagai siri' hanyalah persoalan yang sangat memalukan dan menyangkut pelecehan terhadap martabat seseorang maupun keluarganya.

Sementara di sisi lain, masyarakat Gowa yang memandang persoalan siri' tidak perlu diselesaikan dengan kekerasan, sebab mereka menganggap segala persoalan dapat diselesaikan dengan damai secara kekeluargaan, lagi pula negara Indonesia merupakan negara hukum sehingga segala persoalan yang menyangkut tindak pidana maupun perdata dapat dan harus diselesaikan lewat jalur hukum negara.

Falsafah siri' di Kabupaten Gowa mempunyai peran kontrol pada masyarakat, sebab mereka terkadang takut berbuat sesuatu yang dapat merugikan dirinya sendiri (appakasiri') yang menyebabkan status sosialnya menjadi rendah di 
tengah-tengah masyarakat. Namun ada juga masyarakat yang menyalahartikan siri' pada saat ini, karena mereka menganggap bahwa merupakan siri' (diartikan siri-siri') atau malu-malu apabila temannya mempunyai kendaraan (motor atau mobil), sedangkan dia belum mampu memilikinya.

\section{Pengaruh Falsafah Pacce dalam Kehidupan Masyarakat Suku Makassar di Kabupaten Gowa}

Falsafah Pacce pada masyarakat suku Makassar di kabupaten Gowa merupakan tradisi untuk saling membantu kepada keluarga, kerabat, teman dan siapa saja yang membutuhkan bantuan kita. Kesadaran masyarakat untuk saling membantu, menolong dan menghibur kerabat yang sedang mengalami musibah dapat terlihat pada kasus kematian, bencana alam, kebakaran dan beberapa musibah lainnya. Selain itu, masyarakat di daerah tersebut juga saling membantu pada proses pernikahan kerabatnya, yaitu agar proses pesta pernikahan dapat berlangsung meriah, maka mereka saling memberi sumbangan atau bantuan, baik tenaga maupun materi sesuai kemampuan yang mereka miliki.

Bentuk lain dari pengaruh falsafah pacce pada masyarakat Gowa, yaitu mereka saling membantu membangun rumah, bekerja secara bergotong royong masih sering dilakukan untuk kepentingan bersama, masyarakat beramairamai membuat saluran air untuk digunakan mengairi persawahan mereka. Pengaruh falsafah pacce tersebut dalam kehidupan masyarakat di Gowa masih sering dijumpai, walaupun sebenarnya sudah ada sebagian kecil masyarakat yang menganggap segala sesuatu sudah harus dihitung dengan materi, artinya saya siap bekerja bila saya diberi upah yang memadai.

Selain pengertian dan makna pacce yang dicontohkan tersebut, terdapat pula makna dan sikap pacce yang lebih luas, bahkan lebih mendalam maknanya dibanding pengertian siri'. Pacce lebih mendalam sifatnya dibandingkan siri'. Misalnya bila ada kerabat terkena musibah atau kesusahan sedangkan saya tidak mampu membantunya, bila siri' yang dikedepankan, maka saya terpaksa meninggalkannya. Sedangkan bila pacce yang saya kedepankan, maka saya akan tetap tinggal dan hidup bersama-sama dalam penderitaan. Sikap hidup inilah yang perlu dikedepannya, yaitu sikap senasib sepenanggungan dan bersamasama berusaha merubah hidup ke arah yang lebih baik.

Oleh karena itu, falsafah siri' dan pacce masing-masing memiliki sisi positif dan negatif. Pada sebagian besar masyarakat Gowa yang menganggap dampak positif yang ditimbulkan oleh falsafah siri' dan pacce lebih besar 
dari dampak negatifnya. Hal ini karena mereka menilai bahwa siri' dapat memelihara dan mengontrol mereka dari perbuatan tercela dan dilarang, baik dipandang dari segi agama, adat, maupun hukum negara. Sedangkan pacce dapat memberikan motivasi kepada kita untuk saling menolong antar sesama anggota masyarakat.

Sedangkan masyarakat Gowa yang menganggap bahwa dampak positif yang ditimbulkan oleh falsafah siri' dan pacce kadang-kadang lebih besar dari dampak negatifnya karena mereka menganggap bahwa kasus-kasus siri' dan sering menimbulkan persoalan kriminal tergantung bagaimana seseorang menanggapi persoalan tersebut, sehingga apabila seseorang mampu menahan diri dan melihat tujuan Siri' yang sebenarnya, maka dampak positif dari falsafah tersebut akan dapat terwujud. Sedangkan pacce apabila didasari atas keterdesakan tanpa memperhitungkan kerugian yang akan diderita, maka hal tersebut malah dapat merugikan diri kita sendiri.

Sementara masyarakat Gowa yang menganggap bahwa dampak positif yang ditimbulkan oleh falsafah siri' dan pacce tidak lebih besar dari dampak negatifnya, karena mereka menganggap bahwa siri' hanya membawa kita ke persoalan kriminal akibat kekerasan yang dilakukan. Sedangkan dampak negatif pacce, yaitu bila di depan kita kerabat atau teman dekat teraniaya, maka timbul perasaan pacce dan keinginan untuk melakukan pembalasan akibat perasaan sakit yang diderita oleh kerabat kita, sehingga bila hal ini sangat menonjol, maka pembalasan akan langsung dilakukan tanpa perlu mengetahui penyebab terjadinya persoalan tersebut.

\section{Falsafah Siri' dan Pacce pada Masyarakat Suku Makassar di Kabupaten Gowa Perspektif Syariat Islam}

Agama Islam merupakan agama universal yang mencakup berbagai masalah, baik persoalan hukum, ekonomi, hubungan antar manusia maupun hubungan manusia dengan Penciptanya, sehingga segala masalah yang terjadi di muka bumi ini dapat dijawab oleh agama Islam.

Dengan demikian agama Islam mampu menanggapi budaya-budaya yang berkembang di tengah-tengah masyarakat sebagai hasil tingkah laku masyarakat terhadap lingkungannya. Sebab budaya yang berkembang di tengah-tengah masyarakat merupakan hasil kesepakatan dan menjadi ikatan buat kehidupan masyarakat yang meyakini budaya tersebut.

Adanya kemungkinan akulturasi timbal balik antara Islam dan budaya lokal menurut Russel yang dikutip Madjid bahwa diakui dalam suatu kaidah 
atau ketentuan dasar dalam ilmu ushul al figh, bahwa adat itu dihukumkan (al adah muhakkamah) atau adat adalah syari'ah yang dihukumkan (al adah syari'ah muhakkamah) artinya adat atau kebiasaan suatu masyarakat, yaitu budaya lokalnya adalah sumber hukum dalam Islam (Madjid, 2000: 549).

Kaitannya dengan falsafah sebagai salah satu unsur budaya lokal yang dapat atau harus dijadikan sumber hukum ialah yang sekurang-kurangnya tidak bertentangan dengan prinsip Islam dengan sendirinya harus dihilangkan atau diganti. Inilah makna kehadiran Islam di suatu tempat atau negeri, karena itu setiap masyarakat Islam mempunyai massa jahiliyahnya, yaitu masa yang diliputi oleh praktek-praktek yang berlawanan dengan ajaran tauhid serta ajaran-ajaran lain dalam Islam, seperti tata sosial dalam hukum (laotik), takhayul, mitologi, feodalisme, ketidakpedulian terhadap nasib orang kecil yang tertindas, pengingkaran hak asasi, perlawanan terhadap prinsip persamaan umat manusia dan seterusnya. Semuanya harus ditiadakan dan diganti dengan ajaran-ajaran Islam tentang tauhid atau paham Ketuhanan Yang Maha Esa (dengan implikasi terkuat anti pemujaan segala alam dan sesama manusia (cultism), tertib hukum, rasionalitas, penilaian berdasarkan kenyataan dan pandangan ilmiah, penghargaan sesama manusia atas dasar prestasi dan hasil kerja, keadilan sosial, paham persamaan antara umat manusia (al musawah, egalitarianisme), dan seterusnya.

Oleh karena terciptalah suatu kesepakatan yang dibuat oleh manusia dan menjadi aturan serta pedoman hidupnya dapat diistilahkan dengan kata qanun. Pengertian qanun ialah undang-undang produk manusia yang materinya berusaha memandang manusia dari sisi hak-haknya (al Qardhawiy, 1996: 108). Maksudnya, segala hasil undang-undang yang dibuat atau kesepakatan manusia hanya mengatur hak-hak manusia yang tidak boleh diganggu atau dikuasai oleh orang lain, sehingga tugas qanun berperan untuk membentuk aturan sesuai dengan apa yang diketahui atau dilakukan oleh manusia yang berupa kegiatan muamalah dan tradisi. Ia tidak memandang apakah aktivitas muamalah dan tradisi tersebut merusak atau membahayakan umat umat yang lain. Sedangkan syariat Islam memandang manusia dari sisi tugas kewajiban dan sesuatu yang harus ditaati dan syariat berperan mengembangkan, memajukan dan membebaskan manusia dari tekanan hawa nafsu.

\section{Pandangan Syariat Islam tentang Falsafah Siri}

a. Siri' yang Berarti Perasaan Malu

Siri' bila diterjemahkan sebagai perasaan malu apabila melakukan 
perbuatan yang tercela dan upaya untuk tetap menjaga sikap agar tidak menyebabkan rendahnya harga diri seseorang, maka hal tersebut sesuai dengan ajaran Islam, sebagaimana hadits yang diriwayatkan oleh Muttafaqun Alaihi, Rasulullah saw: al hayu al aytiy ill bikhair (malu itu tidak membuahkan kecuali kebaikan) (Ya'qub, 1996: 111).

Maksud dari hadits tersebut, yaitu perasaan malu yang dimiliki oleh seseorang harus dipertahankan karena akan membuahkan kebaikan, baik pada dirinya maupun pada orang di sekitarnya, dan apabila seseorang memiliki perasaan tersebut, maka dia akan berhati-hati dalam berbicara dan bertingkah laku. Rasulullah SAW, bersabda: "jika engkau tidak malu, berbuatlah apa yang engkau kehendak”. (HR Bukhori). Hadits tersebut merupakan kata sindiran kepada seseorang yang apabila melakukan perbuatan yang dia kehendaki dengan menuruti hawa nafsunya, yaitu perbuatan yang dilarang oleh agama atau perbuatan tercela lainnya maka orang tersebut tidak mempunyai perasaan malu dan termasuk golongan orang yang lemah imannya.

Perasaan malu (siri') bila dipandang dari segi syariat Islam, maka perasaan malu tersebut termasuk sebagian dari iman (Bahreisy, 1986: 545).

Hadits tersebut dapat terlihat apabila pengertian siri' diarahkan ke hal-hal positif, maka orang yang berpegang pada falsafah tersebut termasuk orang yang memperkokoh agama Allah SWT dan sebagai upaya untuk mempertebal keimanan dan ketakwaan kepada Allah SWT, contoh: seseorang yang menganggap siri' apabila agamanya (Islam) dilecehkan dan rela mati untuk membela agamanya, maka hal tersebut akan mempertebal keimanannya kepada Allah. Selain itu membela kehormatan diri dan keluarga juga termasuk perintah Allah SWT.

Perasaan malu atau sifat kemalu-maluan adalah salah satu unsur pendorong yang kuat bagi seseorang untuk berkelakuan baik dan menjauhi yang buruk dan jahat (Sabiq, 1994: 12). Maksudnya apabila seseorang sudah tidak memiliki rasa malu lagi, maka dia tidak akan segan-segan melakukan segala pelanggaran moral dan perbuatan dosa.

Pemahaman tentang falsafah siri' ini pada masyarakat suku Makassar di Kabupaten Gowa pada dasarnya pemaknaannya sama dengan konsep yang ada dalam syariat Islam. Hal ini tergambar dari ketika di masyarakat tersebut ada yang kawin lari (silariang, nilariang, dan erang kale), perzinahan, perkosaan, perbuatan salimarak, yaitu perbuatan hubungan seks yang dilarang karena adanya hubungan keluarga yang terlalu dekat, misalnya perkawinan antara ayah dengan putrinya, ibu dengan putranya, maka dianggap perbuatan siri'. 
b. Siri' yang Berarti Dorongan untuk Berusaha dan Bekerja

Selain itu, bila siri' diterjemahkan sebagai dorongan untuk berusaha dan bekerja demi memperoleh kehidupan yang lebih baik, maka hal tersebut sesuai dengan firman Allah SWT: "Sesungguhnya Allah tidak akan mengubah keadaan suatu kaum, sehingga mereka mengubah keadaan yang ada dalam diri mereka" (QS ar Ra'du: 11).

Ayat tersebut memberikan pemahaman bahwa apabila seseorang ingin memperoleh kehidupan yang lebih baik, maka dia harus berusaha dengan kemampuannya sendiri. Kaitannya dengan budaya siri', yaitu apabila seseorang menganggap siri' bila tidak mampu memperoleh kehidupan yang layak dan hal ini menjadi faktor pendorong untuk berusaha memperbaiki hidupnya maka budaya siri' tersebut sesuai dengan syariat Islam. Seseorang yang ingin memperoleh kehidupan yang lebih baik dengan harapan kehidupan tersebut dapat menunjangnya untuk semakin mendekatkan diri kepada Allah SWT. dan meningkatkan ketakwaannya kepada Allah SWT, maka hal tersebut akan memperkokoh keimananya

c. Siri' Diartikan sebagai Dorongan untuk Membinasakan Orang Lain

Apabila siri' diterjemahkan sebagai dorongan untuk membinasakan orang lain, maka untuk menanggapi persoalan ini, maka harus diketahui terlebih dahulu penyebab lahirnya dorongan siri' tersebut. Adapun penyebab lahirnya dorongan siri' ini antara lain:

1. Karena dipermalukan atau direndahkan harga diri, keluarga atau kerabatnya. Dalam Islam dianjurkan untuk saling memaafkan, sehingga apabila ada seseorang yang melakukan penghinaan terhadap orang lain maka sebaiknya digunakan jalan damai atau saling memaafkan.

2. Karena dipermalukan atau direndahkan agamanya. Dalam Islam apabila seseorang telah menghina dan menginjak-injak kehormatan Agama Islam, maka orang tersebut halal diperangi. Seseorang yang melaksanakan siri' tersebut, maka bila dipandang dari segi aqidah Islam orang tersebut semakin memperkokoh keimanannya kepada Allah SWT, siri' mempunyai perangai saja'ah, yaitu berani karena yakin berada dipihak yang benar.

Pada sebagian masyarakat Gowa memahami bahwa pelaksanaan siri' pada saat sekarang sudah sesuai dengan ajaran Islam karena adanya kesadaran untuk melaksanakan syariat Islam di tengah tengah masyarakat. Namun pada sebagian masyarakat lainnya menganggap bahwa pelaksanaan siri' pada saat sekarang kadang-kadang sudah sesuai dengan ajaran Islam. Hal ini disebabkan sikap dan perilaku masyarakat terkadang masih mengutamakan emosionalnya 
dibanding pikirannya.

Selain itu terdapat pula masyarakat Gowa yang menganggap bahwa pelaksanaan siri' pada saat sekarang tidak sesuai dengan ajaran Islam, Hal ini disebabkan oleh pandangan mereka bahwa siri' identik dengan kekerasan dan kasus yang terjadi sering mengatasnamakan siri' (pelecehan harga diri), padahal Islam selalu berusaha mencari jalan damai.

Sebenarnya undang-undang (rappang) suku Makassar sejak dahulu sudah sesuai dengan syariat Islam. Hal ini dapat terlihat pada isi Rappang ayat 1 yang berbunyi:

Iamo anne na nanro tuma'bicara angkanaya : ia, iannamo tau anggassengi arenna Allah taala siagang na asseng tongi karaeng tallasaka tamate, ia mi nikana perjanjiang. Na ia nikanaya passitabang napadongkoki limanna ri Korang na na panaik ri ulunna punna lekbak nibaca yasing (barang siapa yang mengetahui (arif) asma Allah swt. dan tahu pula sifat-sifatnya yang baqa, itulah yang dimaksud dengan melaksanakan perjanjian, sedangkan yang dimaksud dengan persetujuan ialah memegang atau menjunjung al Quran pada saat dibacakan surat Yasin (Matthes, 1996: 77)

Dari rappang tersebut sudah jelas bahwa sejak dahulu suku Makassar sudah menjalankan syariat Islam, sehingga budaya siri' pun sudah menyesuaikan diri dengan ajaran Islam. Hanya saja karena sikap emosional masyarakat yang menyebabkan mereka lalai menerapkan syariat Islam.

\section{Pandangan Syariat Islam tentang Falsafah Pacce}

Pacce bila diterjemahkan sebagai perasaan pedih atau ikut merasakan pedih bila melihat penderitaan orang lain maka hal tersebut sesuai dengan ajaran Islam. Namun perasaan pedih tersebut dapat menimbulkan berbagai tindakan yang antara lain:

1. Perasaan Pedih Karena Melihat Keluarga atau Orang Lain Terkena Musibah

Perasaan pedih seperti ini terkadang mendorong kita untuk memberikan bantuan kepada orang tersebut. Hal ini juga diajarkan oleh syariat Islam untuk tolong menolong. Sebagaimana firman Allah SWT. Dalam al Quran surat al Maidah ayat 2: "Mengerjakan kebajikan dan taqwa dan jangan tolong menolong dalam berbuat dosa dan pelanggaran" (QS al Maidah: 2).

Ayat tersebut menjelaskan bahwa kita dianjurkan untuk saling membantu untuk melaksanakan perbuatan yang baik termasuk menolong orang yang terkena musibah. Syariat Islam telah memberikan pedoman kepada umat Muhammad SAW, bahwa dalam kehidupan bermasyarakat senantiasa menerapkan nilainilai kepedulian dan keprihatinan terhadap sesama manusia. Tentunya ini 
merupakan sebuah implementasi terhadap bentuk penghambaan manusia kepada Allah SWT.

2. Perasaan Pedih karena Melihat Keluarga atau Teman Teraniaya

Perasaan pedih ini mendorong kita untuk melakukan tindakan pembalasan terhadap orang yang melakukan penganiayaan tersebut. Bahkan yang lebih parah, terkadang pembalasan tersebut langsung dilaksanakan tanpa berpikir atau mengetahui penyebab terjadinya pemukulan/pengaiayaan tersebut. Dalam Islam dianjurkan untuk tidak bertindak tanpa perhitungan atau melakukan pembalasan bila tidak mengetahui penyebab peristiwa tersebut. Selain karena dapat menimbulkan masalah baru, tindakan main hakim sendiri juga tidak dibenarkan oleh hukum (negara, agama dan adat).

Perasaan pacce yang timbul dari dalam diri suku Makassar merupakan kekuatan moril yang dapat mengikat tali kekeluargaan antar sesama manusia sebab adanya perasaan senasib, sesuku, sebangsa ataupun seagama. Hubungan sosial tersebut dalam ajaran Islam telah diatur dalam al Quran: "Orang-orang mukmin itu adalah bersaudara, sebab itu perdamaikanlah antara dua orang saudaramu, dan takutlah kepada Allah, mudah-mudahan kamu mendapat rahmat" (QS al Hujurat: 10).

Ayat tersebut menjelaskan bahwa seluruh umat Islam adalah bersaudara, artinya setiap muslim dalam bermasyarakat harus mencerminkan sikap kekeluargaan kepada seluruh anggota masyarakat. Sikap kekeluargaan yang dianjurkan dalam Islam bertujuan untuk memberikan dorongan kepada masyarakat untuk saling menolong dan membantu dalam sebuah ikatan emosional untuk merasakan rasa senasib dan penanggungan dalam menghadapi segala rintangan dan cobaan yang datang kepada saudara kita.

Pada sebagian masyarakat Gowa menganggap bahwa pelaksanaan pacce pada saat sekarang sudah sesuai dengan ajaran Islam karena adanya kesadaran untuk melaksanakan syariat Islam di tengah-tengah masyarakat dan kesadaran untuk saling tolong menolong sudah tertanam dalam diri masyarakat tersebut. Sedangkan ada sebagian yang menganggap bahwa pelaksanaan pacce pada saat sekarang kadang-kadang sudah sesuai dengan ajaran Islam. Hal ini disebabkan karena dampak positif yang ditimbulkan oleh falsafah itu, terdapat pula sisi negatifnya, yaitu bila melihat keluarga diganggu, maka sikap emosional akan langsung ditampakkan. Selain itu terdapat pula masyarakat Gowa yang menganggap bahwa pelaksanaan pacce pada saat sekarang tidak sesuai dengan ajaran Islam. Hal ini disebabkan oleh pandangan mereka bahwa pacce identik dengan kekerasan dan ketidakmampuan seseorang untuk menahan diri. 
Dengan demikian untuk menyelaraskan konsep siri' dan pacce terhadap agama Islam terutama pada masyarakat suku Makassar di Kabupaten Gowa, maka langkah yang harus dilakukan ialah dengan memberikan pemahaman kepada masyarakat tentang konsep siri' dan pacce yang sesuai dengan tuntunan agama Islam dan berusaha menerapkan konsep tersebut di tengah-tengah masyarakat.

\section{Simpulan}

Masyarakat suku Makassar yang berdomisili di Kabupaten Gowa pada umumnya masih berusaha mempertahankan tradisi atau budaya suku mereka, di antaranya siri' na pacce. Hal ini dikarenakan mereka mayoritas merupakan penduduk asli yang tinggal turun temurun di daerah tersebut dan mayoritas menganut ajaran Islam.

Siri' ialah perasaan malu apabila melakukan perbuatan tercela atau sikap ingin mempertahankan harga diri terhadap orang yang melecehkannya dan upaya untuk bekerja atau berusaha memperoleh kehidupan yang lebih layak. Sedangkan pacce ialah perasaan yang timbul sebagai wujud solidaritas terhadap kerabat yang menimpa kesusahan dan diwujudkan dalam bentuk memberikan bantuan. Falsafah siri' na pacce masih diperpegangi dan berusaha dilaksanakan oleh masyarakat suku Makassar di Kabupaten Gowa, namun pemahaman dan pelaksanaan budaya tersebut sudah mulai bergeser akibat pengaruh dan pengintegrasian budaya yang berasal dari luar Makassar.

Bila ditinjau dari segi syariat Islam, maka siri' yang berarti perasaan malu apabila melakukan perbuatan tercela dan siri' yang menimbulkan dorongan untuk bekerja atau berusaha memperoleh kehidupan yang lebih baik sesuai dengan ajaran Islam. Adapun siri' yang menimbulkan dorongan untuk membinasakan orang lain, maka Islam menilai dari penyebab terjadinya siri' tersebut. Sedangkan pacce yang timbul karena melihat kerabat tertimpa musibah sesuai dengan ajaran Islam. Adapun pacce yang timbul karena melihat kerabat teraniaya, maka Islam menilai berdasarkan akibat yang ditimbulkannya.

\section{Daftar Pustaka}

Al-Qur'an al-Karim.

Bahreisy, Salim. 1986. Tarjamah Riadhus Shalihin. Jilid I. Cet. XI; Bandung: PT. Al-Ma'arif.

Departemen Agama RI. 2002. Al-Quran dan Terjemahnya. Semarang: PT. Karya 
Toha Putra Semarang.

Koentjaraningrat. 1995. Manusia dan Kebudayaan di Indonesia. (Cet.XV). Jakarta: Djambatan.

Limpo, Syahrul Yasin. 1995. Profil Sejarah, Budaya dan Pariwisata Gowa. (Cet. I). Ujung Pandang: Intisari.

Madjid, Nurcholis. 2000. Islam Doktrin dan Peradaban. Jakarta: Paramadina.

Marzuki, H. M. Laica. 1995. Siri': Bagian Kesadaran Hukum Rakyat Bugis-Makassar (Sebuah Telaah Filsafat Hukum). (Cet.I). Ujung Pandang: Hasanuddin University Press.

Matthes, B. F. 1996. Beberapa Etika dalam Sastra Makassar. Jakarta: Depdikbud.

Mattulada. 1995. Latoa: Satu Lukisan Analitik Terhadap Antropologi Politik Orang Bugis. (Cet.II). Ujungpandang: Hasanuddin University Press.

Moein M.G., Andi. 1990. Menggali Nilai-Nilai Budaya Bugis-Makassar dan Sirik na Pacce. Ujung Pandang: Mapress.

Al-Qardhawi, Yusuf. 1996. Al-Madkhal fi Diraasat asy-Syari'ah al-Islamiyah, terj. Muhammad Zakki dan Yasir Tajid, Membumikan Syariat Islam. (Cet. I). Surabaya: Dunia Ilmu Offset.

Sabiq, Sayyid. 1994. Islamuna. Terj. Zainuddin, Islam Dipandang dari Segi RohaniMoral-Sosial. (Cet. I). Jakarta: PT. Rineka Cipta.

Ya'qub, H. Hamzah. 1996. Etika Islam: Pembinaan Akhlaqurkarimah (Suatu Pengantar). (Cet.VII). Bandung: CV. Diponegoro.

el Harakah Vol.14 No.2 Tahun 2012 